\title{
European
}

Stroke Conference

27th Conference, Athens, Greece, April 11-13, 2018

\section{Abstract e-Book}


S. Karger

Medical and Scientific Publishers Basel · Freiburg · Paris · London · New York $\cdot$ Chennai $\cdot$ New Delhi Bangkok · Beijing · Shanghai · Tokyo · Kuala Lumpur $\cdot$ Singapore $\cdot$ Sydney
Disclaimer

The statements, opinions and data contained in this publication are solely those of the individual authors and contributors and not of the publisher and the editor(s). The appearance of advertisements in the journal is not a warranty, endorsement, or approval of the products or services advertised or of their effectiveness, quality or safety. The publisher and the editor(s) disclaim responsibility for any injury to persons or property resulting from any ideas, methods, instructions or products referred to in the content or advertisements.

Drug Dosage

The authors and the publisher have exerted every effort to ensure that drug selection and dosage set forth in this text are in accord with current recommendations and practice at the time of publication. However, in view of ongoing research, changes in government regulations, and the constant flow of information relating to drug therapy and drug reactions, the reader is urged to check the package insert for each drug for any change in indications and dosage and for added warnings and precautions. This is particularly important when the recommended agent is a new and/or infrequently employed drug.
All rights reserved.

No part of this publication may be translated into other languages, reproduced or utilized in any form or by any means, electronic or mechanical, including photocopying, recording microcopying, or by any information storage and retrieval system, without permission in writing from the publisher or system, without permission in writing from the publisher or,
in the case of photocopying, direct payment of a specified fee to the Copyright Clearance Center (see 'General Information').

(C) Copyright 2018 by S. Karger AG

P.O. Box, CH-4009 Basel (Switzerland)

e-ISBN 978-3-318-06365-3

\section{KARGER}

